\title{
MIA PRISKORN
}

\section{DEL AF FAMILIEN}

\section{Penge og gavegivning i danske udvekslingsfamilier}

De britiske antropologer Jonathan Parry og Maurice Bloch viser i antologien Money and the Morality of Exchange fra 1989, hvorledes forskellige samfund forholder sig moralsk og symbolsk forskelligt til penge. Til trods for at ingen af bogens artikler bygger på feltarbejde i vestlige samfund, er det netop den vestlige befolknings ${ }^{1}$ forhold til penge, bogen hovedsageligt analyserer. De vestlige etnografers forforståelse af penge bliver nemlig tydeliggjort i mødet med den eksotiske felt. Eksempelvis skildrer Bloch sin forlegenhed, da han første gang tog afsked med familien, han havde boet hos $\mathrm{i}$ Madagaskar, og familieoverhovedet forærede ham en ,,betydelig sum penge i madagaskiske pengesedler“, 2 som end ikke lå i en ,rensende“" konvolut (Bloch 1989:165).

Blochs utilpashed ved at tage imod en gave bestående af penge får ham til at fundere over den europæiske diskurs om penge, som ifølge Bloch indebærer, at ,moralsk bindende relationer, især slægtskabsrelationer, skal holdes så langt væk som muligt fra pengetransaktioner" (Bloch 1989:165-6).

Bloch henviser til Marx' analyse af kapitalismen, der antageligvis kendetegner vestlige samfund. I henhold til Marx er kapitalismen nemlig bygget op over et (unaturligt) moralsk modsætningsforhold mellem det private familieliv kendetegnet ved følelser og den offentlige økonomi karakteriseret ved kynisk nyttetænkning (op.cit.:173). I lighed hermed argumenterer den amerikanske sociolog David Schneider for, at slægtskab for nordamerikanere kendetegnes ved kærlighed - eller ,vedvarende diffus solidaritet“ (Schneider 1980:51) - i modsætning til penge, som i hans informanters øjne er et symbol på upersonlige magtrelationer, der tilhører arbejdssfæren (op.cit.:48-9). James Carrier, en anden amerikansk antropolog, arbejder videre med Schneiders opdeling mellem arbejde og hjem, som både er familiens fysiske bopæl og følelsesmæssige ramme (op.cit.:45), og påpeger, at der eksisterer en diskrepans mellem ideal og realitet: Skønt hjem/arbejdssted og følelser/økonomi i Nordamerika tænkes som hinandens modsætninger, foregår der konstant overlap mellem kategorierne: Økonomi indblandes i folks private sociale forhold i form af gensidig hjælp, og forhold mellem kolleger og forretningspartnere er ligeledes kendetegnet ved diffuse følelser, der ellers hovedsageligt tilskrives hjemmets sociale relationer (Carrier 1995a:192-7).

Hvert år bruger flere hundrede udenlandske unge mellem 20.000 og $50.000 \mathrm{kr}^{3}$ på at komme et halvt eller et helt år til Danmark, hvor de skal bo hos en værtsfamilie og gå 
i skole eller udføre frivilligt socialt arbejde. Værtsfamiliernes materielle forpligtelse over for udvekslingsstudenterne er kost og logi. Til trods for at udvekslingsstudenten har betalt for sit ophold, virker værtsfamilierne på frivillig basis og modtager ikke økonomisk dispensation for de ekstraudgifter, der er forbundet med at have udvekslingsstudenten boende. Udvekslingsorganisationen AFS skriver eksempelvis i sit informationsmateriale:

Udvekslingsstudenten medbringer selv lommepenge og tøj til et års forbrug og får dækket udgifterne til skoletransport, nationale møder m.v. Jeres families største bidrag er at give udvekslingsstudenten et hjem og en familie i den tid, han/hun er i Danmark. Derudover kan udgifter til mad ikke undgå at stige en smule som følge af det ekstra familiemedlem (AFS Interkultur n.d.:2, original kursivering).

Samme organisation åbner dog for den mulighed, at den enkelte værtsfamilie selv tager stilling til, hvor den økonomiske grænse mellem dem og udvekslingsstudenten skal gå:

Det er individuelt, hvilken del af de daglige fornødenheder (toiletartikler, vaskemidler m.v.), der er til 'fri afbenyttelse' for AFS'eren, og hvilke ting han/hun selv skal sørge for. Han/hun må have det forklaret af jer, så der ikke opstår misforståelser af den grund. [...] Omkostninger ved rejse og fornøjelser, som tilrettelægges af og foretages sammen med værtsfamilien, påhviler som sagt stipendiaten selv, medmindre I ønsker at give et tilskud eller har budgetteret med at betale hele rejsen som en del af jeres udgifter som værtsfamilie (AFS Interkultur 2002:15).

YFU, en anden organisation, lægger tilmed op til, at værtsforældrene skal give udvekslingsstudenten lommepenge, hvis deres egne børn modtager sådanne:

Hvis I giver jeres egne børn lommepenge for at udføre en speciel opgave, vil det være hensigtsmæssigt at finde en løsning, som vil gøre studenten ligestillet med resten af familien (YFU-Danmark:20).

De indledende afsnits skitse af økonomisk antropologisk litteratur påviste et diffust og ofte ikke italesat forhold mellem penge og familie. Ovenstående citater fra udvekslingsorganisationerne AFS og YFU vidner om, hvorledes danske værtsfamilier anbefales at eksplicitere deres families økonomiske regler over for og af hensyn til udvekslingsstudenterne. På grund af denne italesættelse af noget ellers uudsagt kan danske udvekslingsfamilier fungere som et vindue til, hvorledes penge spiller ind på danske familierelationer. Artiklen diskuterer udvekslingsstudenters og værtsfamiliers mulighed for at knytte økonomiske bånd til hinanden. Derudover argumenterer den, at der eksisterer et giver-modtager-forhold mellem udvekslingsstudent og værtsfamilie, og at en fælles, men stiltiende erkendelse af dette forhold er nødvendigt for at skabe en form for social forbundethed mellem parterne, som begge vil værdsætte.

Artiklen bygger på et feltarbejde udført i Danmark fra juli til og med december 2003, hvor jeg deltog i aktiviteter arrangeret af fire forskellige ungdomsudvekslingsorganisationer - AFS Interkultur, Dansk ICYE, Rotary og YFU-Danmark ${ }^{4}$ - og besøgte ni „udvekslingsfamilier“ $i$ tre omgange. Termen udvekslingsfamilie, som er min egen, betegner den samlede enhed bestående af udvekslingsstudent og værtsfamilie og antyder intet normativt om parternes indbyrdes forhold. 
Nogle af udvekslingsfamilierne, jeg fulgte, omtalte ikke penge som et konfliktemne (i det mindste ikke mens jeg var til stede), mens andre gjorde det i mindre grad. Pengeproblematikker var dog særligt fremtrædende i tre af familierne, og artiklen er bygget op over en analyse af en case, der omhandler en udvekslingsfamilies pengekontrovers. Generelt skyldtes nogle konflikter, at udvekslingsstudenten og værtsfamilien udviste forskellige måder at anvende deres penge på. Denne sammenhæng mellem på den ene side forbrugsmønstre og økonomisk sans og på den anden side en persons eller families selvfølelse bliver dog kun berørt let her. Ved dels at skildre udvekslingsstudentens ideelle position i værtsfamilien dels herskende forestillinger om, hvordan forældre bør behandle deres børn, argumenterer jeg i stedet, at problematikken i den udvalgte case bunder $\mathrm{i}$, at udvekslingsorganisationerne forventer en bestemt økonomisk opførsel fra værtsforældrene, som disse har svært ved at efterleve.

\section{Udvekslingsstudenten som barn af værtsforældrene}

Samtlige udvekslingsorganisationer lægger op til, at udvekslingsstudenten skal opføre sig og behandles som et familiemedlem. Udvekslingsstudentens unge alder betyder dog, at vedkommendes rolle er mere specifik end som så - nemlig barn af familien. I YFU-Danmarks materiale kommer dette bl.a. til udtryk ved, at

... det forventes af dem [udvekslingsstudenterne], at de skal dele normalt ansvar som andre i samme aldersgruppe - med de samme pligter og rettigheder (YFU-Danmark:20).

AFS skriver ligeledes, at det

tit vil være mest naturligt [for udvekslingsstudenten] at bruge de samme kaldenavne [for værtsforældrene], som jeres egne børn benytter (AFS Interkultur 2002:7).

Som disse og før refererede citater viser, betyder udvekslingsstudentens rolle som barn i værtsfamilien, at udvekslingsorganisationerne for det første forventer, at værtsforældrene skal behandle udvekslingsstudenten på samme måde som deres eventuelt øvrige børn, eksempelvis ved at forvente samme arbejdsindsats og belønne denne ens. For det andet skal udvekslingsstudenten forsøge at agere på linje med sine værtssøskende og f.eks. kalde værtsforældrene, hvad værtssøskende kalder dem.

Udvekslingsorganisationernes retningslinjer til værtsforældre om, hvordan de bør behandle deres udvekslingsstudent, er udtryk for det i Vesten eksisterende ideal om lighed, som generelt resulterer i en norm om, at forældre skal behandle deres børn ens. Som et eksempel herpå pointerer den danske antropolog Iben Attrup Madsen (2004:4952) i sit studie af danske plejebørns slægtskabsforståelse således, hvor vigtigt det er, at plejebørn oplever, de bliver behandlet som plejeforældrenes egne børn. Ved højtider som jul og fødselsdage lægger plejebørnene nøje mærke til, om deres gaver fra plejeforældrene ser ud til at have kostet lige så meget som gaverne til familiens egne børn, hvilket visse plejeforældre er opmærksomme på og handler ud fra.

Min undersøgelse bekræfter Madsens pointe. Den franske udvekslingsstudent Philippe var således skuffet over, at han havde fået færre fødselsdagsgaver end sin værtsbror, hvis fødselsdagsfest Philippe også havde deltaget i. Philippe var desuden 
skuffet over, at han ikke havde fået det, han havde ønsket sig, såsom en Warhammerfigur. I stedet havde han fået en Marilyn Manson-cd, som han kun for sjov havde sagt, han kunne lide, og to bøger, hvoraf han havde den ene $\mathrm{i}$ forvejen, og den anden antageligvis var kedelig. Philippe syntes, hans værtsbror og han skulle behandles ens. Hans skuffelse bunder i, at hans værtsforældre ikke kender ham så meget, som de kender deres egen søn, eftersom de ikke formåede at tyde hans delvist uklare gaveønsker og som et resultat heraf endte med at forære ham nogle ting, der ifølge Philippe ikke afspejlede ham. Lige så problematisk som Philippe oplever sin situation, kan forfordeling af værtssøskende i forhold til en udvekslingsstudent imidlertid også være, og mit empiriske materiale indeholder flere eksempler herpå.

Som artiklen hidtil har vist, er udvekslingsorganisationernes udmeldinger til værtsforældrene tvetydige: På den ene side skal værtsfamilien blot sørge for kost og logi til udvekslingsstudenten, og på den anden side skal værtsforældrene behandle udvekslingsstudenten, som var det deres eget barn. Kløften består i, at forældres ansvarsområde over for deres egne børn generelt anses som dækkende over mere end blot ernæring og husly. De tvetydige retningslinjer medfører, at udvekslingsfamilierne må forhandle den økonomiske karakter af deres forhold. Den følgende case skildrer et værtsforældrepars forsøg på ikke at forskelsbehandle deres udvekslingsstudent og egen datter materielt.

\section{„Det har man jo ikke penge til“}

Estiske Kadri ${ }^{5}$ på 18 år gik i gymnasiets 2. g og boede hos familien Poulsen, der består af forældrene Sonja og Poul, der er i 50'erne, samt deres datter Tina, som er jævnaldrende med Kadri. Under mit interview med familien fortalte Poul: „Kadri støvsuger gang og køkken og bryggers hver dag.“ Da jeg senere vendte tilbage til emnet og spurgte, om familien havde bedt Kadri om dette, svarede Tina: „Det var først og fremmest fordi, vi skulle på studietur,“ og Sonja fortsatte:

Det får man at vide den første uge, man kommer, og det har man jo ikke penge til. Og så syntes vi ikke, at Tina skulle af sted på studietur, når Kadri ikke skulle, vel? Og Tina har jo selv betalt sin. Så sagde vi, at Kadri kunne låne pengene af os, ved at hun støvsugede. Så hun fik bare sin løn på forskud, så hun kan komme med.

Ved en senere lejlighed fortalte Sonja mig, at Kadris mor ifølge Kadri havde lånt penge, for at Kadri kunne komme på udveksling, og bl.a. på baggrund heraf drog Sonja og Poul den konklusion, at Kadri sandsynligvis ikke ville kunne tage med på studieturen af økonomiske grunde. Sonja og Poul mente, at turen ville gavne Kadris forhold til sine klassekammerater, og som det fremgår af citatet, kunne de ikke forlige sig med tanken om, at deres egen datter Tina, der også gik i 2. g, skulle tage af sted på studieturen uden Kadri. Kadri havde nemlig som udvekslingsstudent uden arbejdstilladelse ikke mulighed for selv at betale for studieturen ved at tage sig et regulært fritidsarbejde ligesom Tina. Poul og Sonja tilbød derfor Kadri en daglig arbejdsopgave, støvsugning, til gengæld for studieturen, og Kadri indvilligede i aftalen. Kadri og Tina var på en god studietur sammen, og Kadri støvsugede så godt som dagligt under sit ophold i Danmark. 
Ud over Kadris studietur så Sonja og Poul sig nødsaget til også at betale for Tinas studietur, da de ikke ville gøre forskel på de to, og Sonja måtte tage ekstra vagter på sit arbejde for at betale for den uforudsete udgift. Som tiden gik, viste det sig, at Kadris families økonomi var bedre, end familien Poulsen først havde antaget. Under alle omstændigheder så og hørte familien beviser for Kadris families betragtelige forbrug: Pakke efter pakke med nyt tøj samt et dyrt digitalkamera fra Kadris mor ankom til familiens hjem, og familien Poulsen hørte også om Kadris families ferie til Ægypten. Tina blev misundelig over tingene, som Kadri modtog fra sine estiske forældre, da Tina var vant til selv at skulle tjene penge, før hun kunne købe sig noget nyt. Sonja og Poul fortrød, at de havde betalt for Kadris (og Tinas) studietur, for som Sonja betroede mig: „Så mange penge har vi altså heller ikke.“ Familien skulle eksempelvis ikke på ferie det år, tilføjede Sonja. Familien drøftede imidlertid ikke situationen med Kadri, og Sonja slog fast, at der jo ikke var noget at gøre ved det nu.

\section{Udvekslingsstudenten - barn i værtsfamilien økonomisk set?}

Casen viser, at to faktorer forstyrrer den økonomiske illusion om familieskab, fordi de skaber andre vilkår for udvekslingsstudenten end for værtsfamiliens egne børn: For det første modtager udvekslingsstudenten penge fra andre instanser (egne forældre og/ eller udvekslingsorganisationen) end værtsforældrene, og for det andet er udvekslingsstudenten afskåret fra at påtage sig erhvervsarbejde i sin fritid, hvilket flertallet af danske unge tjener (ekstra) lommepenge ved. Sonja og Pouls forsøg på at behandle Tina og Kadri ens er således dømt til at mislykkes, da det aldrig vil resultere i en reel lighed.

Mit etnografiske materiale indeholder både eksempler på udvekslingsstudenter, som har færre og flere midler til rådighed end deres værtssøskende. Begge dele kan forårsage problemer i udvekslingsfamilierne, fordi den økonomiske forskel går imod det generelle ideal om søskendes lige vilkår, som udvekslingsorganisationerne lægger op til, og som mange værtsforældre også sigter imod.

Casens konflikt bunder dog ikke udelukkende i de forskellige økonomiske vilkår for udvekslingsstudenter og værtssøskende. Familien Poulsen forærer Kadri studieturen på baggrund af et fejlskøn af hendes families økonomi. Artiklens anden halvdel vil dels diskutere grunden til dette fejlskøn, dels hvordan familien tackler situationen og endelig årsagen til, at fejlskønnet får så stor en betydning for måden, hvorpå værtsfamilien forholdt sig til deres udvekslingsstudent.

\section{Almisse, gave eller løn?}

I casen henvises til, at Kadris mor havde betalt udvekslingsopholdet med lånte penge, men efter min vurdering bunder fejlskønnet $\mathrm{i}$ lige så høj grad i værtsfamiliens forventninger til en udvekslingsstudent fra et baltisk land: Familien Poulsen foretrak nemlig en udvekslingsstudent fra Estland frem for en fra Tyskland, som var de eneste nationaliteter, familien kunne vælge imellem, eftersom de meldte sig forholdsvis sent som værtsfamilie. Tyskland var ifølge Tina „for tæt på“, og Poul syntes, at det „måske [var] mere spændende fra Estland“. Sonja gav en tredje beslægtet grund: , ,...] vi syntes 
måske også, at vi bedre kunne give dem et eller andet også." Sonja uddybede hverken, hvad hun mente med at „give“, eller hvad hun havde tænkt sig at „give“. I lyset af ovenstående eksempel tyder denne udtalelse dog på en sammenhæng mellem familien Poulsens præference for en udvekslingsstudent fra et baltisk land og deres forestillinger om borgere fra tidligere kommunistiske lande som væsentlig anderledes og materielt ringere stillet end danskere. Som udgangspunkt foretrækker familien med andre ord en udvekslingsstudent, der er så forskellig fra dem som muligt, og som mindrebemidlet angiveligt bedst gør sig fortjent til deres opmærksomhed.

Som følge af værtsfamiliens forventninger til Kadris økonomi betragtede familien og Kadri sandsynligvis betalingen af Kadris studietur vidt forskelligt: På trods af Sonjas bedyrelse af at betalingen blot var „løn på forskud“, var det i realiteten ikke sådan, værtsforældrene anskuede situationen: Hvis de havde anset støvsugningen som decideret betaling for studieturen på linje med Tinas fritidsjob, havde de nemlig ikke haft nogen grund til også at betale for Tinas studietur. Sonja og Poul betalte for Kadris studietur, fordi de bedømte, hun ikke selv havde mulighed herfor, og fordi de syntes, hun skulle med på turen.

Ifølge Dansk Etymologisk Ordbog (Nielsen 1989) stammer almisse fra det græske ord for medlidenhed og barmhjertighed og kan følgelig defineres som „en frivillig barmhjertighedsgave til trængende nødstedte“ (Bang 1977). I lyset af denne begrebsbestemmelse finder jeg det sandsynligt, at Sonja og Poul betragtede betalingen af Kadris studietur som en almisse. For at forhindre, at Kadri skulle opleve modtagelsen heraf som et tab af værdighed og i sidste ende måske ikke tage med på turen, slørede de, at der var tale om en almisse og udtænkte støvsugerordningen, som Kadri skulle opfatte som et jævnbyrdigt lønforhold.

Familien snakkede som nævnt ikke om kontroversen med Kadri, og over for mig nævnte Kadri aldrig betalingsordningen for studieturen, hvorfor jeg må gisne om, hvordan Kadri har opfattet aftalen: Har hun set den som en retfærdig og jævnbyrdig udveksling (en studietur for daglig rengøring), som Sonja lægger op til ved at beskrive turen som „løn på forskud“? Har Kadri betragtet studieturen som en gave på linje med de ting, Kadri er vant til, at hendes egne forældre forærer hende? Eller har Kadri været klar over, at betalingen af studieturen var tænkt som en almisse, som støvsugningen blot skulle dække over, og som hun valgte at tage imod for ikke at skulle bede sine egne forældre om flere lommepenge?

\section{Det asymmetriske giver-modtager-forhold}

At udvekslingsstudenten ideelt set opfattes og behandles som værtsforældrenes barn, har den konsekvens, at forholdet mellem udvekslingsstudent og værtsforældre bør være asymmetrisk. Forholdet mellem forældre og børn er nemlig nødvendigvis ulige i løbet af barnets første mange leveår, hvor det anses som forældrenes opgave at yde materiel og emotionel støtte til deres børn, så de med tiden kan udvikle sig til selvhjulpne individer. ${ }^{6}$ Forældre indtager således rollen som givere og deres børn rollen som modtagere. ${ }^{7}$

Alene udvekslingsstudentens associering med sine værtssøskende får den konsekvens, at vedkommende antager en modtagerrolle. To andre faktorer bidrager yderligere til 
etableringen af et asymmetrisk udvekslingsforhold: For det første flytter udvekslingsstudenten ind i værtsfamiliens hjem, og hele konceptet bag ungdomsudveksling er, at det er udvekslingsstudenten, der skal foretage langt den største grad af tilpasning til familiens normer. For det andet indtager værtsfamilien rollen som giver ved ikke at modtage økonomisk kompensation for ekstraudgifter forbundet med udvekslingsstudentens ophold, hvilket efterlader udvekslingsstudenten i rollen som modtager.

Ifølge den franske sociolog Marcel Mauss er modtagerrollen imidlertid problematisk, idet modtagelsen af en gave forpligter en gengældelse heraf. Fra det tidspunkt, giveren forærer en gave, til modtageren er i stand til at gengælde den, har modtageren med Mauss' ord „en gave 'på ryggen'“ (2000:60). Hele udvekslingsopholdet kan i dette lys ses som en kontinuerlig proces, hvor udvekslingsstudenten med forskellige midler bør og i de fleste tilfælde også forsøger at tilbagebetale værtsfamilien, så et mere balanceret forhold opstår. I forlængelse heraf vil jeg nu diskutere, om skabelsen af den slags familiebånd, som alle parter bedømmer som overvejende positive, afhænger af, hvorvidt værtsforældre på den ene side er i stand til at leve op til giverrollen, og om udvekslingsstudenten på den anden side formår at udfylde positionen som modtager.

\section{Det ideelle gaveforhold}

For at besvare dette spørgsmål må jeg vende blikket mod teorier om, hvordan gavegivning bør foregå. Den franske samfundsteoretiker Pierre Bourdieus supplement til Mauss' gaveteori er at han påpeger vigtigheden af det tidsinterval, der forløber mellem gave og modgave: Ifølge Bourdieu har tidsintervallet den funktion: ,,... at skærme gave og modgave af fra hinanden, og at give to helt igennem symmetriske handlinger mulighed for at fremstå som unikke handlinger uden forbindelse til hinanden“" (Bourdieu 1994:176, original oversættelse).

Til trods for at både giver og modtager er klar over, at en gave forpligter modtageren og således har det resultat, at giveren får magt over modtageren, ønsker begge at sløre denne realitet: Den oprindelige gave skal således fremstå lige så ,formåls-løs“ og ,gratis“ som modgaven (op.cit.:176). Ifølge Bourdieu samarbejder giver og modtager således om ,... en hemmeligholdelsesproces, der har en tendens til at fornægte sandheden om udvekslingens logik, dvs. at der er tale om et noget-for-noget-forhold“ (op.cit.:177, original oversættelse).

Hemmeligholdelsen i familien Poulsen og Kadris tilfælde er dog af en anden karakter end den, som Bourdieu refererer til. I stedet for at det er tiden, der slører, at gave og modgave er direkte forbundne, går casens hemmeligholdelse nemlig ud på at maskere, at der overhovedet er tale om en gave: Som allerede skildret opfattede Sonja og Poul studieturen som en barmhjertighedsgave, men forsøgte at sløre dette forhold over for Kadri, hvorfor det ikke er sikkert, at hun i det hele taget opfattede studieturen som en gave.

Som følge af denne usikkerhed var hverken værtsforældre eller udvekslingsstudent i stand til at leve op til deres respektive roller som giver og modtager: Sonja og Poul fortrød deres gave til Kadri, da den blev givet på et ufuldstændigt vidensgrundlag om Kadris økonomiske situation. I et ideelt gaveforhold ønsker giveren ikke at omstøde foræringen af en gave, men i værtsforældres øjne levede Kadri ikke op til rollen som 
modtager, fordi det viste sig, at hun i realiteten ikke havde samme behov for gaven, som værtsforældrene oprindeligt havde antaget. Som allerede berørt er en mulig konsekvens af hemmeligholdelsen af studietursbetalingens karakter, at Kadri ikke opfattede den som en gave. Dermed gengældte hun den ikke på passende vis og levede ikke op til rollen som modtager.

Lad mig sætte casen i relation til noget af min øvrige empiri: Andre værtsfamilier har i modsætning til familien Poulsen ekspliciteret aspekter af udvekslingsforholdet. En værtsmor fandt det eksempelvis upassende, at familiens udvekslingsstudent ville modtage flere tusinde kroner i månedlige lommepenge ${ }^{8}$ og således ,tjene“ på sit „gratis“ ophold hos familien. Værtsmoren handlede på sin følelse af, at det økonomiske forhold mellem udvekslingsstudenten og familien var i ubalance, og fik den lokale Rotaryklub til ikke at give udvekslingsstudenten yderligere lommepenge. Som i familien Poulsen bunder værtsmorens vurdering sandsynligvis $i$, at udvekslingsstudentens høje månedlige indtægt udfordrede den ideelle lighed mellem søskende, idet familiens børn ikke modtog nogen lommepenge. Ved ikke at give børn lommepenge, men i stedet give dem penge til specifikke udgifter opnår forældre større grad af økonomisk kontrol med deres børn en kontrol værtsforældrene ikke havde over udvekslingsstudenten i dette tilfælde, hvilket forrykkede magtbalancen i familien, som igen fik værtsmoren til at forsøge at genvinde den.

Et andet værtsforældrepar nøjedes med at eksplicitere udvekslingens logik over for mig. Deres udvekslingsstudent havde spurgt dem, om han måtte tage med nogle venner på kasino, hvilket de ikke havde givet ham lov til. Værtsfaren forklarede mig deres beslutning med, at udvekslingsstudenten ikke skulle „drikke champagne og smide om sig med penge på et kasino“, når familien havde inviteret udvekslingsstudenten med på flere ferier. „Sådan bruger vi ikke vores penge her i familien!“ slog værtsfaren fast. Noget-for-noget-relationen mellem værtsfamilie og udvekslingsstudent i denne familie gik med andre ord ud på, at hvis udvekslingsstudenten skulle nyde godt af familiens goder, så forventede de til gengæld, at han økonomisk skulle opføre sig som et familiemedlem og ikke anvende sine penge på en i deres øjne upassende og unødvendig kasinotur.

I de hidtil omtalte udvekslingsfamilier var pengekontroverser imidlertid blot én af mange dynamikker, der spillede ind på det indbyrdes forhold, og aktørernes sans for udvekslingens logik var i de fleste tilfælde mere udviklet på andre områder. I udvekslingsfamilierne indbefatter den generelle udveksling nemlig i lige så høj grad dagligdagens immaterielle handlinger, så som en humoristisk bemærkning, hjælp med madlavningen eller dyrkningen af en fælles interesse.

Mit empiriske materiale indeholder også eksempler på udvekslingsfamilier, hvor hemmeligholdelsesprocessen tilsyneladende har fungeret i en sådan grad, at både udvekslingsstudent og værtsfamilie har været enige om udvekslingens logik uden at have ekspliciteret den. En udvekslingsfamilie berettede eksempelvis om forskellige gaver, som de i tråd med Bourdieus teori ikke satte i forbindelse med hinanden: Efter at have set sin værtsmors samling af fingerbøl, der var udstillet i en glasmontre på stuevæggen, sendte udvekslingsstudenten således bud efter et fingerbøl fra sit hjemland, som værtsmoren begejstret viste mig, da jeg besøgte familien for første gang. Til juletid forærede værtsmoren bl.a. udvekslingsstudenten hjemmesyede gaver af sælskind, som også faldt i god jord. 
Årsagen til begge gavers succes er, at de både sagde noget om modtageren og giveren: Fingerbøllet var specielt udvalgt til værtsmoren på grund af hendes samling og var samtidig et minde om udvekslingsstudenten ved at være fra hendes hjemland. Gaven understregede derudover udvekslingsstudentens position som barn af familien, fordi værtsmorens egne børn ofte havde foræret hende fingerbøl, da de var mindre. Sælskindsgaverne betonede ligeledes mor-datter-forholdet mellem værtsmoren og udvekslingsstudenten. Værtsmoren havde nemlig de foregående år syet hjemmesko og vanter til de øvrige familiemedlemmer, og gaver af sælskind vidner således om, at værtsmoren betragter udvekslingsstudenten som endnu et familiemedlem.

Hvor min analyse af familien Poulsen-casen viser, i hvor høj grad ulige økonomiske vilkår mellem udvekslingsstudent og værtssøskende kan komplicere skabelsen af familiebånd, viser dette eksempel derimod, hvorledes gaver kan bidrage til at indskrive udvekslingsstudenten i rækken af egne børn. Inspireret af den norske antropolog Signe Howells (2003) begreb ,kinning“, der i hendes felt betegner adoptivforældres aktive forsøg på at placere adoptivbørn i forældrenes netværk af familie og venner, betragter jeg gaveudvekslingen i det netop omtalte eksempel som en succesfuld „slægtende strategi“. Disse gavers eksplicitte status som gaver og vægten på deres ikke-monetære værdi - i modsætning til casens slørede pengegave - understreger endnu engang penges problematiske status i familierelationer.

\section{Konklusion}

I indledningen viste jeg, hvorledes penge i vestlige samfund tænkes afgrænset fra den private familiesfære, og artiklen har bidraget til at slå fast, at økonomi og familie i realiteten ikke lader sig adskille til trods for, at sammenhængen for det meste er uudtalt. Når en familie åbner sit hjem for en udvekslingsstudent, bliver det imidlertid ofte nødvendigt at eksplicitere familiens uskrevne regler inklusive de økonomiske - om ikke over for udvekslingsstudenten så over for sig selv eller en besøgende antropolog. Udvekslingsfamilierne fungerer derfor i denne artikel som et vindue til, hvorledes penge spiller ind på sociale relationer i danske familier.

Artiklens hovedpointe er, at skabelsen af social forbundethed i udvekslingsfamilier kompliceres af, at udvekslingsstudenten og værtssøskende ikke har samme økonomiske vilkår, hvilket strider imod idealet om søskendelighed. Derudover argumenterer jeg for, at værtsforældre indtager rollen som givere over for udvekslingsstudenten, der er modtager, og at en bevidsthed om dette forhold, samt hvorvidt parterne er i stand til at leve op til deres respektive roller, spiller ind på udvekslingsfamiliens mulighed for at skabe et familielignende forhold, som de betragter som positivt.

Min undersøgelse peger på, at de udvekslingsfamilier, der fik indbyrdes problemer af økonomisk karakter, er familier med børn på samme alderstrin som udvekslingsstudenten, hvorimod de udvekslingsstudenter, der ikke oplevede større økonomiske kontroverser med værtsfamilien, enten havde udeboende eller betydeligt yngre værtssøskende eller slet ikke havde værtssøskende. Det kan derfor tilrådes at forsøge at skabe så ens økonomiske vilkår for udvekslingsstudenter og eventuelle jævnaldrende værtssøskende samt at kommunikere åbent omkring de økonomiske forskelle, der ikke lader sig udjævne. 


\title{
Noter
}

Flere personer har været involveret i tilblivelsen af denne artikel. Jeg takker min specialevejleder Tine Tjørnhøj-Thomsen for sin både yderst gavmilde og skarpsindige hjælp, min skrivegruppe bestående af Dorte Nørregaard Gotthardtsen, Maria Møller Kristensen og Rie Raffing for løbende opmuntring og gode iagttagelser, Clara Rübner Jørgensen for gensidig kritik under udarbejdelsen af hver vores artikler, min mor Annette Priskorn for hjælp med det engelske resumé samt Tidsskrift for Antropologis pengetemaredaktion og to anonyme anmeldere for konstruktive forslag til at styrke artiklens argumenter.

1. Det kan diskuteres, præcis hvilke lande „Vesten“og dermed den vestlige befolkning dækker over. Som den britiske antropolog Marilyn Strathern påpeger: ,[...] there is no general Western population as such. There are only a mass of differences between people who image themselves as Westerners" (Strathern 1992:28).

2. I forbindelse med udenlandske citater oversat til dansk er oversættelserne mine egne, medmindre andet er angivet.

3. Beløbet afhænger af, hvilken organisation udvekslingsstudenten benytter, og hvilket land den unge er fra (des tættere på Danmark, des billigere pga. transportudgifterne). Rotary skiller sig økonomisk ud fra de andre tre udvekslingsorganisationer, idet udvekslingsstudenternes ophold i værtslandet (i dette tilfælde Danmark) sponsoreres af lokale Rotaryklubber, således at den unge udelukkende betaler for flybillet og forsikring.

4. I artiklen omtales organisationerne i deres forkortede form som henholdsvis AFS, ICYE, Rotary og YFU. AFS står for American Field Service, og ICYE er forkortelse af International Christian/Cultural Youth Exchange (oprindeligt stod c'et i ICYE for „Christian“, men flere lande - heriblandt Danmark - har efterfølgende valgt at lade c'et stå for „cultural“, da de mener, det bedst repræsenterer, hvad de står for). YFU er en forkortelse for Youth For Understanding.

5. Ifølge aftale med mine informanter er deres navne udskiftet med pseudonymer.

6. Se Ortner (1997) for en skildring af, hvorledes den økonomiske støtte blandt nordamerikanske middelklassefamilier kan række mange år ind i deres børns voksenliv, idet forældrene ønsker at sikre deres børn et vist økonomisk niveau.

7. Denne rollefordeling kommer tydeligt til udtryk i forbindelse med julen, den årlige vestlige begivenhed, hvor flest materielle objekter skifter ejermand: I sit studie af julen i USA's „Middletown“ finder den amerikanske sociolog Theodore Caplow således, at forældre giver markant flere og dyrere gaver til deres (især yngre) børn, end de modtager (Carrier 1995b:57).

8. Udvekslingsstudenten fik 1900 kroner udbetalt om måneden, fordi han tog en særlig gymnasiel uddannelse, hvor elever under 18 år modtager et offenligt tilskud til kost og logi, såfremt forældrene ikke bor i nærheden. Den lokale Rotaryklub ville derudover give ham 600 kroner i lommepenge om måneden, hvorfor udvekslingsstudentens samlede månedlige indkomst således ville have været på 2500 kroner.

\section{Litteraturliste}

\author{
AFS Interkultur \\ 2002 Håndbog for værtsfamilier. Frederiksberg: AFS Interkultur \\ n.d. Værtsfamilie. En uforglemmelig oplevelse. Frederiksberg: AFS Interkultur.
}

Bang, Jørgen (red.)

1977 Gyldendals Tibinds Leksikon. København: Gyldendal.

Bloch, Maurice

1989 The Symbolism of Money in Imerina. I: J. Parry \& M. Bloch (eds.): Money and the Morality of Exchange. Cambridge, New York \& Melbourne: Cambridge University Press.

Bourdieu, Pierre

1994 Af praktiske grunde. Omkring teorien om menneskelig handlen. København: Hans Reitzels Forlag. 


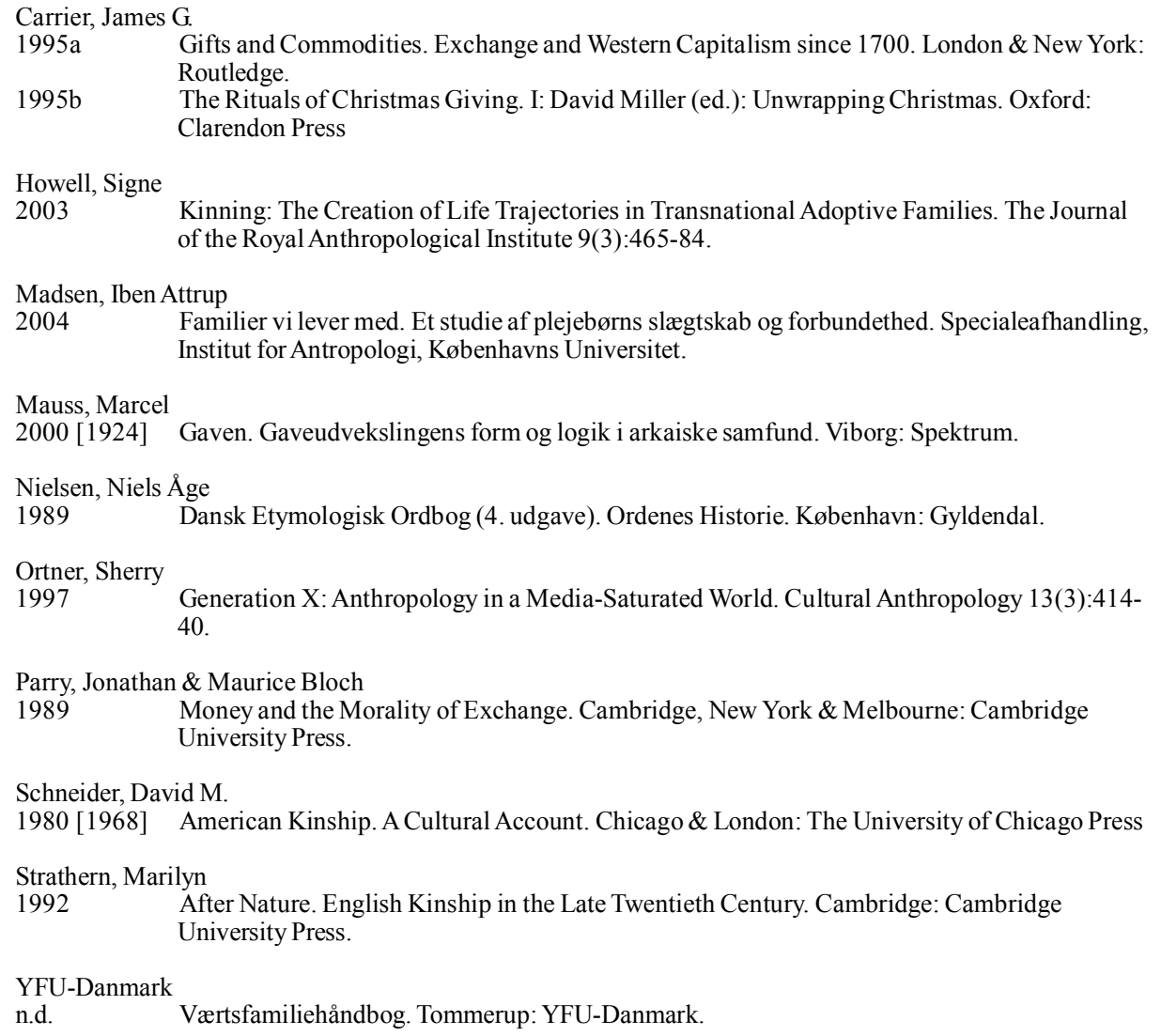


